Journal of Telenursing (JOTING)

Volume 1, Nomor 2, Desember 2019

e-ISSN: 2684-8988

p-ISSN: 2684-8996

DOI: https://doi.org/10.31539/joting.v1i2.787

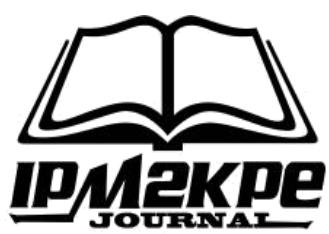

\title{
PENGARUH TERAPI AIUEO TERHADAP KEMAMPUAN BICARA PASIEN STROKE YANG MENGALAMI AFASIA MOTORIK
}

\author{
Afnijar Wahyu ${ }^{1}$, Liza Wati ${ }^{2}$, Murad Fajri ${ }^{3}$ \\ Sekolah Tinggi Ilmu Kesehatan Hang Tuah Tanjungpinang ${ }^{1,2,3}$ \\ wafniwahyu@gmail.com ${ }^{1}$
}

\begin{abstract}
ABSTRAK
Tujuan dari penelitian ini untuk mengetahui pengaruh terapi AIUEO terhadap kemampuan bicara pasien stroke yang mengalami afasia motorik di RSUD Raja Ahmad Thabib Tanjungpinang. Desain penelitian yang digunakan adalah quasi experimen dengan pendekatan nonequivalent control group design. Hasil penelitian menunjukkan terdapat perbedaan yang bermakna kemampuan fungsional komunikasi antara kelompok kontrol dan perlakuan dengan nilai $\mathrm{p}<0,05(p=0,007$ pada $\mathrm{a}=0,05)$ dengan menggunakan uji statistik wilcoxon test. Simpulan, adanya pengaruh terapi AIUEO terhadap kemampuan bicara pasien stroke dengan afasia motorik pada kelompok perlakuan dan kelompok kontrol di RSUD Ahmad Thabib Tanjungpinang.
\end{abstract}

Kata Kunci: Kemampuan Bicara, Stroke Afasia Motorik, Terapi AIUEO

\section{ABSTRACT}

The purpose of this study was to determine the effect of AIUEO therapy on the speech ability of stroke patients who have motor aphasia in Raja Ahmad Thabib Hospital Tanjungpinang. The research design used was quasi experiment with the Nonequivalent Control Group Design approach. The results showed that there were significant differences in the functional ability of communication between the control and treatment groups with a value of $p<0.05(p=0.007$ at $a=0.05)$ using the Wilcoxon Test statistical test. Conclusion, the influence of AIUEO therapy on the speech ability of stroke patients with motor aphasia in the treatment and control groups at Ahmad Thabib Hospital Tanjungpinang.

Keywords: Speech Ability, Motor Aphasia Stroke, AIUEO Therapy

\section{PENDAHULUAN}

Stroke merupakan kelainan fungsi otak yang timbul secara mendadak dan terjadi pada siapa saja kapan saja. Penyakit ini menyebabkan kecacatan berupa kelumpuhan anggota gerak, gangguan bicara, proses pikir, sebagai akibat gangguan fungsi otak (Muttaqin, 2011). Penyebab penyakit stroke salah satunya karena tingginya tekanan darah, akibat lebih tinggi tekanan darah, lebih besar jumlah kerusakan vascular dan dapat memicu pecahnya pembuluh darah (Padila, 2012).

Menurut World Health Organization (WHO) tahun 2018 stroke merupakan salah satu masalah kesehatan yang utama didunia. Stroke menempati peringkat ketiga penyebab kematian, pada tahun 2013 terdapat 5,5 juta orang meninggal dan meningkat sebanyak 12\% pada tahun 2018 yaitu sekitar 14 juta orang (WHO, 2018). 
Berdasarkan hasil Riskesdas tahun 2018 prevelensi penyakit Stroke di Indonesia meningkat seiring bertambahnya umur. Kasus Stroke tertinggi yang terdiagnosis tenaga kesehatan berada diwilayah Kalimantan Timur, sedangkan Kepulauan Riau berada pada urutan ke 4 di Indonesia. Indonesia mengalami peningkatan kasus stroke dari $7 \%$ pada tahun 2013 menjadi 10,9\% pada tahun 2018 (Riskesdas, 2018).

Masalah keperawatan yang muncul akibat stroke sangat bervariasi, tergantung luas daerah otak yang mengalami infark atau kematian jaringan dan lokasi yang terkena (Rasyid \& Lyna, 2007). Stroke yang menyerang otak kiri dan mengenai pusat bicara, kemungkinan pasien akan mengalami gangguan bicara atau afasia, karena otak kiri berfungsi untuk menganalisis, pikiran logis, konsep, dan memahami bahasa (Sofwan, 2010).

Gangguan fungsi saraf lokal dan atau global, secara mendadak, progresif dan cepat adalah ciri khas penyakit stroke. Gangguan fungsi saraf pada stroke disebabkan oleh gangguan peredaran darah otak non traumatik maupun traumatik. Gangguan saraf tersebut menimbulkan gejala antara lain: kelumpuhan wajah atau anggota badan, bicara tidak lancar, bicara tidak jelas (pelo), mungkin perubahan kesadaran, gangguan penglihatan, dan lain-lain (Rischter, 2015).

Secara umum Afasia terjadi menjadi 3 jenis, yaitu Afasia Motorik, Afasia Sensorik dan Afasia Global (Mulyatsih \& Airiza, 2008). Afasia motorik, kerusakan (yang pada umumnya disebut lesion) terjadi pada daerah borca. Karena daerah ini berdekatan dengan jalur korteks motor maka yang sering terjadi adalah alat-alat ujaran, termasuk bentuk mulut menjadi terganggu, kadang-kadang mulut bisa miring (Anonim, 2014).

Orang yang mengalami gangguan bicara atau afasia akan mengalami kegagalan dalam berartikulasi. Artikulasi merupakan proses penyesuaian ruangan supraglottal. Penyesuaian ruangan didaerah laring terjadi dengan menaikkan dan menurunkan laring, yang akan mengatur jumlah transmisi udara melalui rongga mulut dan rongga hidung melalui katup velofaringeal dan merubah posisi mandibula (rahang bawah) dan lidah. Proses diatas yang akan menghasilkan bunyi dasar dalam berbicara (Yanti, 2012).

Salah satu bentuk terapi rehabilitasi gangguan Afasia adalah dengan memberikan terapi AIUEO. Terapi AIUEO bertujuan untuk memperbaiki ucapan supaya dapat dipahami oleh orang lain. Orang yang mengalami gangguan bicara atau Afasia akan mengalami kegagalan dalam berartikulasi. Artikulasi merupakan proses penyesuaian ruangan supraglottal. Penyesuain ruangan didaerah laring terjadi dengan menaikkan dan menurunkan laring, yang akan mengatur jumlah transmisi udara melalui rongga mulut dan ronggahidung melalui katup velofaringeal dan merubah posisi mandibula (rahang bawah) dan lidah. Proses diatas yang akan menghasilkan bunyi dasar dalam berbicara (Yanti, 2012).

Didalam penelitian Sofiatun et al., (2012) mengatakan bahwa responden lebih efektif diberikan terapi AIUEO karena responden lebih mudah untuk menirukan pembentukan vokal, gerak lidah, bibir, dan rahang. Sedangkan jika diberikan terapi The Token Test responden kesulitan untuk menyebutkan benda yang ditunjukkan oleh peneliti. Oleh karena itu terapi AIUEO sangat efektif dalam penanganan pada pasien stroke dengan afasia motorik.

Berdasarkan studi pendahuluan yang dilakukan peneliti di RSUD Ahmad Thabib, dari data 10 besar kasus pasien rawat inap dan jalan di RSUD Ahmad Thabib didapat penyakit syaraf berada pada urutan ke tiga sebanyak 20\% dari 851 jumlah kasus, didapat jumlah Stroke ditahun 2017 pada kunjungan rawat inap sebanyak 171 orang, 
sedangkan pada Triwulan I tahun 2018 kunjungan rawat inap pada pasien stroke sebanyak 55 orang. Diperkirakan disetiap bulan ada 18 orang kunjungan rawat inap untuk kasus stroke (RSUD Ahmad Thabib, 2017).

\section{METODE PENELITIAN}

Penelitian ini merupakan penelitian quasi experimental dengan menggunakan nonequivalen control group design dipilih satu kelompok, selanjutnya dari satu kelompok tersebut yang setengah diberi perlakuan terapi AIUEO selama 1 bulan dan setengah lagi tidak. Sampel yang diambil dalam penelitian ini adalah purposive sampling. Penelitian bini dilakukan di RSUD Ahmad Thabib Tanjungpinang dengan menggunakan total sampling dengan samel sebanyak 18 responden. Setelah jumlah sampel ditetapkan, maka jumlah sampel akan menjadi 2 kelompok penelitian yaitu terdiri dari 9 kelompok perlakuan dan 9 kelompok kontrol. Hal ini sesuai dengan rancangan penelitian yang digunakan yaitu rancangan nonequivalent control group design.

Analisis yang digunakan dalam penelitian ini adalah uji wilcoxon test yaitu untuk melihat pengaruh kemampuan bicara pasien stroke yang mengalami afasia motorik sebelum dan sesudah terapi AIUEO pada kelompok perlakuan di RSUD Ahmad Thabib Tanjungpinang dan pengaruh kemampuan bicara pasien stroke yang mengalami afasia motorik sebelum dan sesudah terapi AIUEO pada kelompok kontrol di RSUD Ahmad Thabib Tanjungpinang, sedangkan untuk mengetahui pengaruh kemampuan bicara.

\section{HASIL PENELITIAN}

Tabel.1

Karakteristik Responden Berdasarkan Umur dan Jenis Kelamin $(n=18)$

\begin{tabular}{cccccc}
\hline \multirow{2}{*}{ Karakteristik } & \multicolumn{2}{c}{ Kelompok Perlakuan } & \multicolumn{2}{c}{ Kelompok Kontrol } \\
& & $\mathrm{N}$ & $(\%)$ & $\mathrm{n}$ & $(\%)$ \\
\hline \multirow{2}{*}{ Umur } & $40-49$ & 2 & $22 \%$ & 0 & $0 \%$ \\
& $50-59$ & 7 & $78 \%$ & 3 & $33 \%$ \\
& $60-69$ & 0 & $0 \%$ & 6 & $67 \%$ \\
\hline \multirow{2}{*}{ Jenis Kelamin } & Laki-laki & 6 & $67 \%$ & 7 & $78 \%$ \\
& Perempuan & 3 & $33 \%$ & 2 & $22 \%$ \\
\hline
\end{tabular}

Berdasarkan tabel 1 hasil analisis data diatas sebagian besar responden memiliki rentang umur dari 50-59 tahun dengan persentasi 78\%, sedangkan berjenis kelamin lakilaki yaitu $67 \%$ pada kelompok perlakuan.

Tabel. 2

Kemampuan Bicara Kelompok Perlakuan Sebelum dan sesudah Terapi AIUEO $(n=18)$

\begin{tabular}{lcccc}
\hline Kemampuan Bicara & \multicolumn{2}{c}{ Pre Test } & Post Test \\
& $n$ & $f(\%)$ & $n$ & $f(\%)$ \\
\hline Baik & 1 & $11 \%$ & 7 & $78 \%$ \\
Sedang & 8 & $89 \%$ & 2 & $22 \%$ \\
Kurang Baik & 0 & $0 \%$ & 0 & $0 \%$ \\
\hline \multicolumn{1}{c}{ Jumlah } & 9 & $100 \%$ & 9 & $100 \%$ \\
\hline
\end{tabular}


Berdasarkan tabel 2 dapat dilihat peningkatan kemampuan bicara pada kelompok perlakuan sebelum dan sesudah dilakukan terapi AIUEO. Dari 9 responden pada kelompok perlakuan pada saat pre-test didapat $89 \%$ responden berkemampuan bicara sedang. Hasil pada saat post-test didapat $78 \%$ responden berkemampuan bicara baik.

Tabel. 3

Kemampuan Bicara Kelompok Kontrol Sebelum dan Sesudah Terapi AIUEO

\begin{tabular}{ccccc}
\hline Kemampuan Bicara & \multicolumn{2}{c}{ Pre Test } & \multicolumn{2}{c}{ Post Test } \\
& $n$ & $f(\%)$ & $n$ & $f(\%)$ \\
\hline Baik & 2 & $22 \%$ & 1 & $11 \%$ \\
Sedang & 7 & $78 \%$ & 8 & $89 \%$ \\
Kurang Baik & 0 & $0 \%$ & 0 & $0 \%$ \\
\hline Jumlah & 9 & $100 \%$ & 9 & $100 \%$ \\
\hline
\end{tabular}

Berdasarkan tabel 3 dapat dilihat nilai kemampuan bicara pada kelompok kontrol sebelum dan sesudah terapi AIUEO, didapatkan dari 9 responden $78 \%$ memiliki kemampuan bicara sedang, pada saat pre-test dan pada saat post-test bertambah menjadi $89 \%$ yang memiliki kemampuan bicara sedang.

Tabel. 4

Pengaruh Kemampuan Wicara Pasien Stroke yang Mengalami Afasisa Motorik Sebelum dan Sesudah Terapi AIUEO pada Kelompok Perlakuan ( $\mathrm{n}=9)$

\begin{tabular}{cc}
\hline Kelompok Perlakuan Sebelum dan Sesudah Terapi AIUEO & $P$ Value \\
& 0,007 \\
\hline
\end{tabular}

Berdasarkan tabel 4 menggunakan uji wilxocon di dapatkan nilai p-value 0,007 maka dalam penelitian ini ada pengaruh terapi AIUEO terhadap kemampuan bicara pasien stroke dengan afasia motorik.

\section{PEMBAHASAN}

Stroke adalah gangguan saraf permanen akibat terganggunya peredaran darah ke otak, yang terjadi sekitar 24 jam atau lebih (Lingga, 2013). Stroke merupakan gangguan peredaran darah otak yang menyebabkan defisit neurologis mendadak sebagai akibat iskemia atau hemoragi sirkulasi saraf otak (Nanda, 2012).

Keluhan utama yang sering dirasakan pasien stroke adalah pasien sulit berbicara (pelo) dan sering merasa sakit kepala (pusing). Sulit berbicara dan sakit kepala merupakan salah satu menifestasi klinik stroke hal ini sesuai dengan teori yang mengatakan bahwa sering pusing, mengalami gangguan kognitif dan deminsia ketika berkomunikasi dengan orang lain (Lingga, 2013). Berbicara sulit (pelo) merupakan salah satu manifestasi klinik hal ini sesuai dengan teori yang mengatakan bahwa mengalami gangguan kognitif dan demensia ketika berkomunikasi dengan orang lain (Lingga, 2013).

Kemampuan bicara kelompok perlakuan sebelum dan sesudah diberikan terapi AIUEO pada pasien stroke yang mengalami afasia motorik di RSUD Ahmad Thabib Tanjungpinang. Terjadi peningkatan kemampuan bicara pada kelompok perlakuan sebelum dan sesudah dilakukan terapi AIUEO. Dari 9 responden pada kelompok perlakuan pada saat pre-test didapat $89 \%$ responden berkemampuan bicara sedang. 
Hasil pada saat post-test didapat $78 \%$ responden berkemampuan bicara baik. Hal ini terlihat jelas terdapat peningkatan yang signifikan pada kelompok perlakuan setelah dilakukan terapi AIUEO selama 1 bulan.

Afasia motorik adalah kesulitan berkata-kata tetapi dapat mengerti pembicaraan. Afasia motorik timbul akibat gangguan pada pembuluh darah karotis internal, yaitu cabangnya yang menuju otak bagian tengah tepatnya pada cabang akhir, afasia Motorik ini disertai kelemahan lengan lebih berat dari pada tungkai. Afasia motorik disebut juga Afasia Borca. Paul Borca ilmuan Prancis, menemukan suatu area pada lobus frontalis kiri yang jika rusak akan mengakibatkan kehilangan daya pengutaraan pendapat dan perasaan dengan kata-kata. Tidak ada kelumpuhan alat bicara pada gangguan ini. Daerah otak tersebut dikenal sebagai area borca (Mardjono, 2006).

Hal ini juga sejalan dengan teori yang dinyatakan oleh Sunardi (2006) dalam Speech Therapy (Terapi Wicara) Post Laringotomy, yaitu salah satu bentuk terapi rehabilitasi gangguan afasia adalah dengan memberikan terapi wicara salah satunya terapi AIUEO.

Terapi wicara merupakan tindakan yang diberikan kepada individu yang mengalami gangguan komunikasi, ganggyan berbahasa bicara, gangguan menelan. Terapi wicara ini berfokus pada pasien dengan masalah-masalah neurologis, diantaranya pasien pasca stroke.

Terapi AIUEO merupakan terapi untuk membantu seseorang menguasai komunikasi bicara dengan lebih baik. Terapi ini memfokuskan pada perbaikan cara berbicara penderita stroke yang pada umumnya mengalami kehilangan kemampuan bicara akibat adanya saraf yang mengalami gangguan. Terapi wicara membantu penderita untuk mengunyah, berbicara, maupun mengerti kembali kata-kata.

Wardhana (2011) menyatakan bahwa penderita stroke yang mengalami kesulitan bicara akan diberikan terapi AIUEO yang bertujuan untuk memperbaiki ucapan supaya dapat dipahami oleh orang lain. Orang yang mengalami gangguan bicara atau afasia akan mengalami kegagalan dalam berartikulasi. Artikulasi merupakan proses penyesuaian ruangan supraglottal.

Kemampuan bicara kelompok kontrol sebelum dan sesudah terapi AIUEO pada pasien stroke yang mengalami afasia motorik di RSUD Ahmad Thabib Tanjungpinang. Pada tabel 2 dapat dilihat nilai kemampuan bicara pada kelompok kontrol sebelum dan sesudah terapi AIUEO, didapatkan dari 9 responden $78 \%$ memiliki kemampuan bicara sedang pada saat pre-test dan pada saat post-test bertambah menjadi $89 \%$ yangmemiliki kemampuan bicara sedang. Responden mengalami peningkatan sebanyak $11 \%$ dengan katagori sedang. Hal ini terjadi dikarenakan penurunan fungsi komunikasi yang tidak dilatih, karena afasia motorik adalah sebuah gangguan atau penyumbatan pada area borca, sehingga pasien akan mengalami gangguan berbicara serta kegagalan fungsi komunikasi.

Dari hasil penelitian ini dapat disimpulkan bahwa kelompok kontrol yang tidak diberikan terapi AIUEO tidak dapat mengalami perkembangan. Hal ini didorong oleh beberapa faktor antara lain adanya sebagian pasien mengalami gangguan fungsi kognitif yang membuat pasien merasa tidak mampu untuk bersosialisasi seperti sebelumnya dan hal ini bisa membuat seorang penderita stroke mengalami penurunan motivasi untuk pulih. Dikarenakan setiap individu memiliki sifat yang unik, ada sebagian orang memiliki tingkat motivasi yang rendah dan sebagian yang tinggi. 
Teknik AIUEO yaitu dengan cara menggerakan otot bicara yang akan digunakan untuk mengucapkan lambang-lambang bunyi bahasa yang sesuai dengan pola-pola standar seperti huruf A.I.U.E.O dan kosa-kata yang mengandung pola-pola standar. A.I.U.E.O misalnya akar, ikan, udang, ekor dan orang, sehingga dapat dipahami oleh pasien. Hal ini disebut dengan artikulasi organ bicara. Pengartikulasian bunyi bahasa atau suara akan dibentuk oleh koordinasi tiga unsur, yaitu unsur motoris (pernafasan), unsur yang bervibrasi (tenggorokan dangan pita suara), dan unsure yang beresonansi (rongga penuturan: rongga hidung, mulut dan dada) (Gunawan, 2008).

Masalah ini diperjelas oleh Suwantara (2004) bahwa setelah terjadi suatu serangan stroke pasien dapat mengalami motivasi dan fungsi-fungsi kognitif. Pada dasarnya, kemajuan dan kesembuhan penderita sifatnya unik dan individual karena sangat tergantung dari kemauan dan semangat dari masing- masing individu yang sakit. Hal ini sangat dianjurkan pada pasien pasca stroke yang mengalami gangguan bicara karena hanya dengan treatment yang tepat gangguan bicara bisa ditangani.

Orang yang mengalami gangguan bicara atau afasia akan mengalami kegagalan dalam berartikulasi. Artikulasi merupakan proses penyesuaian ruangan supraglottal. Penyesuaian ruangan didaerah laring terjadi dengan menaikkan dan menurunkan laring, yang akan mengatur jumlah transmisi udara melalui rongga mulut dan rongga hidung melalui katup velofaringeal dan merubah posisi mandibula (rahang bawah) dan lidah. Proses diatas yang akan menghasilkan bunyi dasar dalam berbicara (Yanti, 2012).

Salah satu bentuk terapi rehabilitasi gangguan Afasia adalah dengan memberikan terapi AIUEO. Terapi AIUEO bertujuan untuk memperbaiki ucapan supaya dapat dipahami oleh orang lain. Orang yang mengalami gangguan bicara atau Afasia akan mengalami kegagalan dalam berartikulasi. Artikulasi merupakan proses penyesuaian ruangan supraglottal. Penyesuain ruangan didaerah laring terjadi dengan menaikkan dan menurunkan laring, yang akan mengatur jumlah transmisi udara melalui rongga mulut dan ronggahidung melalui katup velofaringeal dan merubah posisi mandibula (rahang bawah) dan lidah. Proses diatas yang akan menghasilkan bunyi dasar dalam berbicara (Yanti, 2012).

Pengaruh kemampuan bicara pasien stroke yang mengalami afasia motorik sebelum dan sesudah terapi AIUEO pada kelompok perlakuan di RSUD Ahmad Thabib Tanjungpinang, dapat dilihat dari data tabel Berdasarkan dari analisis data dengan menggunakan uji Wilcoxon Test didapatkan nilai $p$-value sebesar 0,007 < 0,05, maka penelitian ini ada pengaruh kemampuan bicara pasien stroke dengan afasia motorik sebelum dan sesudah terapi AIUEO pada kelompok perlakuan di RSUD Ahmad Thabib Tanjungpinang.

Hasil penelitian ini sejalan dengan penelitian Dwi et al., (2014) menyatakan bahwa terdapat peningkatan terapi wicara AIUEO pada pasien dengan afasia motorik dengan $p$ - value 0,000. Responden lebih efektif diberikan terapi AIUEO karena responden lebih mudah untuk menirukan pembentukan vokal, gerak lidah bibir, rahang. Terapi AIUEO merupakan tindakan yang diberikan kepada individu yang mengalami gangguan komunikasi. gangguan bahasa dan gangguan bicara yang dibahas berfokus pada terapi bicara pada pasien dengan masalah-masalah dengan neurologis, di antaranya pasca stroke.

Penjelasan ini didukung oleh penelitian Sofiatun et al., (2012) menyatakan bahwa Responden lebih efektif diberikan terapi AIUEO karena responden lebih mudah untuk menirukan pembentukan vokal, gerak lidah bibir, rahang, sedangkan jika diberikan terapi the token test responden kesulitan untuk menyebutkan benda yang ditunjukkan 
olehpeneliti.Pengaruh kemampuan bicara pasien stroke yang mengalami afasia motorik sebelum dan sesudah terapi AIUEO pada kelompok kontrol di RSUD Ahmad Thabib Tanjungpinang.

Disimpulkan bahwa hasil penelitian ini menjadi tidak signifikan disebabkan karena terapi AIUEO yang tidak diberikan kepada kelompok kontrol. Untuk memperbaiki kemampuan bicara pada semua subjek penelitian tergantung dari individu tersebut, karena setiap individu memiliki variasi berbeda dalam proses pemulihan. Faktor-faktor yang dapat mempengaruhi prosespemulihanseperti kemampuan kognitif, umur tua dan kehadiran anggota keluarga yang mendampingi pasien berganti-ganti sehingga peneliti harus memberikan latihan dan penjelasan yang berulang- ulang kepada anggota keluarga. Semua faktor ini tentunya dapat mempengaruhi proses pemulihan pasien.

Hal ini sejalan dengan hasil Ita et al., (2012) dengan hasil diketahuinya bahwa di kategori sebelum dilakukan intervensi paling banyak responden hanya mampu berkomunikasi secara pasif yaitu sebanyak $9(45 \%)$ responden.

Responden lebih efektif diberikan terapi AIUEO karena responden lebih mudah untuk menirukan pembentukan vokal, gerak lidah bibir, rahang. Terapi AIUEO merupakan tindakan yang diberikan kepada individu yang mengalami gangguan komunikasi, gangguan bahasa dan gangguan bicara yang dibahas berfokus pada terapi bicara pada pasien dengan masalah-masalah dengan neurologis, di antaranya pasca stroke.

Penjelasan ini didukung oleh penelitian Sofiatun et al., (2012) menyatakan bahwa Responden lebih efektif diberikan terapi AIUEO karena responden lebih mudah untuk menirukan pembentukan vokal, gerak lidah bibir, rahang, sedangkan jika diberikan terapi the token test responden kesulitan untuk menyebutkan benda yang ditunjukkan oleh peneliti.

Kelebihan terapi AIUEO merupakan terapi yang sangat simpel, tidak membutuhkan alat/media yang digunakan. Dibandingkan dengan terapi lain yang digunakan untuk pasien Afasia. Dengan kelebihan itu perawat bisa melakukan terapi AIUEO sebagai intervensi keperawatan, karna perawat berada 24 jam disamping pasien. Hasil penelitian Dwi et al., (2014) menunjukkan bahwa ada pengaruh terapi AIUEO terhadap kemampuan bicara pada penderita Stroke yang mengalami afasia motorik.

Hasil tersebut juga didukung dengan penelitian sebelumnya oleh Sofiatun et al., (2012) menunjukkan bahwa selama 3 hari didapatkan hasil p-value 0,000, artinya latihan AIUEO memberikan kontribusi yang signifikan terhadap peningkatan kemampuan berbicara pada pasien stroke dengan afasia motorik.

Didalam penelitian Sofiatun et al., (2012) mengatakan bahwa responden lebih efektif diberikan terapi AIUEO karena responden lebih mudah untuk menirukan pembentukan vokal, gerak lidah, bibir, dan rahang. Sedangkan jika diberikan terapi The Token Test responden kesulitan untuk menyebutkan benda yang ditunjukkan oleh peneliti. Oleh karena itu terapi AIUEO sangat efektif dalam penanganan pada pasien stroke dengan afasia motorik.

Terapi AIUEO merupakan terapi untuk membantu seseorang menguasai komunikasi bicara dengan lebih baik. Terapi ini memfokuskan pada perbaikan cara berbicara penderita stroke yang pada umumnya mengalami kehilangan kemampuan bicara akibat adanya saraf yang mengalami gangguan. Terapi wicara membantu penderita untuk mengunyah, berbicara, maupun mengerti kembali kata-kata. 
Teknik AIUEO yaitu dengan cara menggerakan otot bicara yang akan digunakan untuk mengucapkan lambang-lambang bunyi bahasa yang sesuai dengan pola-pola standar seperti huruf A.I.U.E.O dan kosa-kata yang mengandung pola-pola standar. A.I.U.E.O misalnya akar, ikan, udang, ekor dan orang, sehingga dapat dipahami oleh pasien. Hal ini disebut dengan artikulasi organ bicara. Pengartikulasian bunyi bahasa atau suara akan dibentuk oleh koordinasi tiga unsur, yaitu unsur motoris (pernafasan), unsur yang bervibrasi (tenggorokan dangan pita suara), dan unsur yang beresonansi (rongga penuturan: rongga hidung, mulut dan dada) (Gunawan, 2008).

Hal ini juga sejalan dengan teori yang dinyatakan oleh Sunardi (2006) dalam speech therapy (terapi wicara) post laringotomy, yaitu salah satu bentuk terapi rehabilitasi gangguan afasia adalah dengan memberikan terapi wicara salah satunya terapi AIUEO. Terapi wicara merupakan tindakan yang diberikan kepada individu yang mengalami gangguan komunikasi, ganggyan berbahasa bicara, gangguan menelan. Terapi wicara ini berfokus pada pasien dengan masalah-masalah neurologis, diantaranya pasien pasca stroke.

\section{SIMPULAN}

Gambaran kemampuan bicara kelompok perlakuan sebelum dan sesudah dberikan terapi AIUEO pada pasien stroke yang mengalami afasia motorik di RSUD Ahmad Thabib Tanjungpinang selama 1 bulan didapatkan responden sebagian besar yang memiliki kemampuan bicara baik.

Gambaran kemampuan bicara kelompok kontrol sebelum dan sesudah terapi AIUEO pada pasien stroke yang mengalami afasia motorik di RSUD Ahmad Thabib Tanjungpinang didapatkan terjadi peningkatan kemampuan bicara saat diberikan post test.

Diketahui adanya pengaruh kemampuan bicara pasien stroke dengan afasia motorik sebelum dan sesudah terapi AIUEO pada kelompok perlakuan di RSUD Ahmad Thabib Tanjungpinang. Diketahui adanya pengaruh kemampuan bicara pasien stroke dengan afasia motorik sebelum dan sesudah terapi AIUEO pada kelompok kontrol di RSUD Ahmad Thabib Tanjungpinang.

Diketahui adanya pengaruh terapi AIUEO terhadap kemampuan bicara pasien stroke dengan afasia motorik pada kelompok perlakuan dan kelompok kontrol di RSUD Ahmad Thabib Tanjungpinang.

\section{SARAN}

\section{Bagi pelayanan keperawatan}

Pelayanan keperawatan agar dapat lebih meningkatkan lagi asuhan keperawatan pada pasien stroke khususnya yang memiliki gangguan berbicara dengan cara menggunakan metode terapi AIUEO.

\section{Bagi ilmu keperawatan}

Penelitian ini dapat menjadi informasi tambahan bagi perawat khusunya untuk meningkatkan intervensi keperawaratan dalam menambah dan memperkaya pelayanan kesehatan melalui metode non farmokologis dalam mengatasi penyakit stroke khususnya dengan gangguan bicara. 


\section{Bagi penelitian selanjutnya}

Untuk mengatasi gangguan bicara pada pasien stroke yang mengalami afasia motorik, penelitian perlu dilanjutkan dengan melihat faktor-faktor predisposisi seperti motivasi, depresi, dukungan keluarga. Yang nantinya variabel-variabel tersebut dapat dijadikan bahan dalam penelitian selanjutnya dalam masalah penanganan pasien stroke yang mengalami afasia motorik.

\section{DAFTAR PUSTAKA}

Anonim, A. (2014). Stroke Penyebab Kematian Ketiga dan Penyebab Cacat Utama

Dwi, G., Haryanto, A., Setyawan, D., Argo, M., \& Kusuma, B. (2014). Pengaruh Terapi Aiueo terhadap Kemampuan Bicara pada Pasien Stroke yang Mengalami Afasia Motorik di RSUD Tugurejo Semarang. Jurnal Ilmu Keperawatan dan Kebidanan, $1-11$

Gunawan, D. (2008). Buku Artikulasi. Univesitas Pendidikan Indonesia. Jur._Pend._Luar_Biasa/1962112119840 31

Ita, S., Kristiyawati, S. P., \& Eko, S. C. P. (2012). Efektifitas Terapi Aiueo dan Terapi the Token Test terhadap Kemampuan Berbicara Pasien Stroke yang Mengalami Afasia Motorik di RS Mardi Rahayu Kudus. Stikes Telogorejo Semarang

Lingga, L. (2013). Eksplorasi Metodologi SDLC. Sistem Informasi UNIKOM

Mardjono, M., \& Priguna, S. (2006). Neuorologi Klinis Dasar. Jakarta: Dian Rakyat

Mulyatsih, E., \& Airiza, A. (2008). Stroke Petunjuk Perawatan Pasien Pasca Stroke di Rumah. Jakarta: Balai Penerbit FKUI

Muttaqin, A. (2011). Buku Ajar Asuhan Keperawatan Klien dengan Gangguan System Persyarafan. Jakarta: Salemba Medika

Nanda. (2012). Aplikasi Asuhan Keperawatan Berdasarkan Diagnosis Medis \& Nanda. Edisi jilid I. Jakarta: Media Action Publishing

Padila, P. (2012). Buku Ajar Keperawatan Medikal Bedah. Yogyakarta: Nuha Medika

Rasyid, A. L., \& Lyna, S. (2007). Unit Stroke Manajemen Stroke Secara Komprehensif. Jakarta: Balai Penerbit FKUI

Rischter, A., Lewin., Volz, M., Jobges, M., \& Werheid, K. (2015). Predictivity of Early Depressive Symptoms for Post-Stroke Depression. Journal Nutrition Health Aging;Clinical Neuroscience, 19(7)

Riset Kesehatan Dasar. (2018). Badan Penelitian dan Pengembangan Kesehatan Kementerian RI tahun 2018. http://www.depkes.go.id/resources/download/infoterkini/materi_rakorpop_2018/ Hasil\%20Riskesdas\%202018.pdf

Rsud Ahmad Thabib. (2017). Profil Rsud Provinsi Kepri Tanjungpinang Tahun 2016. Tanjungpinang: Provinsi Kepulauan Riau

Sofiatun, I., Kristiyawati, S. P., \& Purnomo, S. E. (2012). Efektifitas Terapi AIUEO dan Terapi The Token Test terhadap Kemampuan Berbicara Pasien Stroke yang Mengalami Afasia Motorik di RS Mardi Rahayu Kudus. Jurnal Ilmu Keperawatan dan Kebidanan, 8(2), 230-238

Sofwan, R. (2010). Anda Bertanya Dokter Menjawab: Stroke dan Rehabilitasi PascaStroke. Jakarta: PT Bhuana Ilmu Populer

Sunardi, S. (2006). Speech Therapy (Terapi Wicara) Post Laringotomy. Nurdinurses.files.com/2008/01/makalah-speech-therapy.pdf

Suwantara, J. R. (2004). Depresi Pasca Stroke: Epidemiologi, Rehabilitasi dan Psikoterapi. Jakarta: Universitas Indonesia 
Wardhana, W. A. (2011). Strategi Mengatasi \& Bangkit dari Stroke. Yogyakarta: Pustaka Belajar

World Health Organization (WHO). (2018). Stroke, Cerebrovascular Accident. Diambil dari http://www.who.int/topics/cerebrovascular_accident/en/

Yanti, D. (2012). Penatalaksanaan Terapi Wicara pada Tuna Rungu. Jakarta: ECG 